\title{
THE STATE OF INTER-ETHNIC RELATIONS IN
}

MACEDONIA AFTER 16 YEARS OF THE OHRID AGREEMENT

\author{
Agon Demjaha \\ State University of Tetovo and South East European University \\ a.demjaha@seeu.edu.mk
}

DOI: $10.1515 /$ seeur-2017-0016

\begin{abstract}
Inter-ethnic relations between Albanians and Macedonians in Macedonia have been rather problematic since the times of former Yugoslavia. After independence, the new constitution of the Republic of Macedonia instead of improving it has further downgraded the position of Albanians and other minorities living in the country. The non-fulfilment of Albanians' core demands led to an armed conflict in 2001. The Ohrid Agreement has in addition to ending the armed conflict, also provided for a range of legislative and policy measures to improve the position of the Albanians by ensuring equality and minority protection. However, 16 years after the Ohrid Agreement, inter-ethnic relations in Macedonia still remain burdened by prejudice and stereotypes, rather than cooperation and
\end{abstract}


mutual prosperity. The main aim of the paper is to analyse the state of inter-ethnic relations in Macedonia, with special focus on relations between ethnic Macedonians and ethnic Albanians. The paper also offers an analysis of main factors that contribute to inter-ethnic tensions in the country and explores possible scenarios in the future. The most relevant part of the paper analyses the causality between inter-ethnic and interstate relations. The paper claims that similarly to most of the countries in the Western Balkans, inter-ethnic and interstate relations are basically the components of the same equation. The paper concludes that in Macedonia, Kosovo rather than Albania is much more relevant for the causality between inter-ethnic and interstate relations in Macedonia, and it also offers several reasons to support such thesis. Accordingly, the overall inter-ethnic relations between Macedonians and Albanians in Macedonia heavily depend on inter-state relations between Macedonia and Kosovo and vice versa.

Key Words: Inter-ethnic relations, Macedonia, Macedonians, Albanians, Inter-state relations

\section{INTRODUCTION}

The dissolution of Former Yugoslavia has had major implications for people that were living in the territory of this state. Huge portions of populations that have enjoyed the status of nations, overnight became national minorities in the states that emerged out of the ashes of Former Yugoslavia. In Macedonia, despite its considerably mixed ethnic and religious population, the main inter-ethnic tensions were manifested 
between ethnic Macedonians and ethnic Albanians, as two major ethnicities in the country. It is worth mentioning that inter-ethnic relations between Albanians and Macedonians in Macedonia have been rather problematic since the times of former Yugoslavia. Nevertheless, these two communities have for decades managed to live with each other peacefully despite obvious difficulties. Albanians in Macedonia have bitter memories from the times of former Yugoslavia and were hoping that independent Macedonia will provide better ground for improvement of their position (Demjaha and Peci, 2015, p. 164). Unfortunately, the new constitution of the Republic of Macedonia instead of improving it has further downgraded the position of Albanians because it defined the country as "the national state of the Macedonian people" rather than "the state of the Macedonian people and the Albanian and the Turkish nationalities" as it had stood before (Constitution of the Republic of Macedonia, 1991). Albanians' core demands - greater representation, recognition of Albanian as an official second language, the right to Albanian-language Higher Education and administrative autonomy at a local government level - remained unmet some 10 years after independence.

Although Macedonia was the only republic of former Yugoslavia that gained its independence in 1991 without warfare in its territory, its independence was followed by enormous external and internal challenges. Externally speaking, Albania did recognize both the Macedonian state and nation, but made it clear that its goodwill would depend on the status of the Albanian minority in Macedonia. Serbia recognized the state de facto by setting up a new Yugoslavia without 
Macedonia, but Serbia has failed to recognize the separate existence of the Macedonian Orthodox Church. Bulgaria recognized the state, but has refused to acknowledge that there is a legitimate Macedonian nation for fear of encouraging secessionist tendencies among the inhabitants of the Bulgarian Macedonia, many of whom have rejected a Bulgarian identity in favour of a Macedonian one. Moreover, Greece opposed Macedonia’s constitutional name and refused to accept that its citizens could legitimately be called Macedonians. (Glenny, 1996, p. 255) Internally, serious concerns were raised in regard to the specific character of its multi-ethnic and multi-confessional composition. Macedonia is a country where minorities represent one-third of the population and where the citizens have different religious affiliations, even within the same ethnic group. Clearly, in such an environment certain amount of social and cultural prejudice was to be expected (Simoska, 1997, pp. 96-98).

The main aim of this paper is to analyse the state of inter-ethnic relations in Macedonia in general, and those between ethnic Macedonians and ethnic Albanians in particular. Throughout the paper, special focus will be given to inter-ethnic relations between these two major ethnicities in the country especially after the signing of the Ohrid Framework Agreement in 2001. The structure of the paper consists of five chapters altogether, including introduction and conclusion. After the introductory chapter, in the second chapter the paper will focus on the state of the current state of affairs of the inter-ethnic relations between Macedonians and Albanians in Macedonia. The third chapter will analyse a set of main factors that contribute to inter-ethnic tensions in the country. In the fourth chapter, special attention will be given to the causality between inter- 
ethnic and interstate relations, namely to the fact that in the countries of the Western Balkans, inter-ethnic and interstate relations are basically the components of the same equation. The paper ends with a concluding chapter that provides a summary of the main findings of our analysis.

\section{INTER-ETHNIC RELATIONS IN MACEDONIA: THE CURRENT STATE OF AFFAIRS}

As already mentioned, the main inter-ethnic tensions in Macedonia were predominantly manifested between ethnic Macedonians and ethnic Albanians, as two major ethnicities in the country. Such relations between these two ethnicities have been rather problematic during the times of former Yugoslavia, especially after a series of Albanian demonstrations in 1981 that asked for the elevation of the status of Kosovo into a republic within the federation. Macedonians feared that such proposed seventh republic that would include Albanian dominated parts of Western Macedonia would have severely truncated the Republic of Macedonia and most probably revived Bulgarian, and even Serbian and Greek claims. Thus the growth of Albanian nationalism in Macedonia was seen as possibly fatal, not only to the territorial integrity of the republic but even to the very existence of the Macedonian nation (Poulton, 1995, p. 127). On the other hand, continuous harsh repressive measures by Macedonian authorities only fuelled Albanian nationalism and their belief that as a distinct national group, like all other nations in Yugoslavia, they had the rights and powers to control and decide their own political and cultural destiny. These processes further widened the 
gap between the two communities, and though the two communities coexisted in the same territory, they became more distrustful of each other.

However, as mentioned earlier, though the constitution of the newly created Republic of Macedonia promised Albanians and other nationalities "full equality as citizens and permanent co-existence with the Macedonian people," the structural inequalities between the ethnic groups persisted, fuelling Albanian resentment (Petroska-Beska and Najcevska, 2004, p. 3). Undoubtedly, in terms of advancing legitimate political and cultural demands, the Macedonian state failed its Albanian minority. As a result, Albanians boycotted the national referendum on the independence of Macedonia in 1991 and staged their own unofficial referendum on territorial autonomy for western Macedonia (Ortakovski, 2001, p. 34). When a similar formula was adopted in the Preamble to the 1991 Constitution, Albanian political elites again protested against these developments and demanded that the Albanians living in Macedonia should be given a status of the constituent nation. In addition to other measures, Albanian MPs also boycotted the voting on new constitution in the Parliament (Daskalovski, 2013, p. 369). Nevertheless, the democratization of the political life in the Republic of Macedonia created conditions for the ethnic Albanians to form their own political structure by means of which to defend the interests of their community. As a result, most of the Albanian efforts for improving their position within Macedonia were mainly done institutionally through their legally elected representatives of Albanian political parties. Still, core demands of the Albanians remained unmet some 10 years after independence. 
Such reality led to an armed conflict between ethnic Albanian rebels and government forces in 2001. Although the conflict ended rather quickly, it resulted in an overall number of 200 casualties, 64 among NLA fighters, 63 among the Macedonian security forces, and about 60 civilians were reported to have lost their lives (Daskalovski, 2003, p. 65). In addition, due the actions undertaken by the Macedonian security forces and NLA some 150,000 people have been internally displaced, while only until May 2001 there were about 42,000 refugees from Macedonia registered in Kosovo (Balalovska, 2006, p. 18). Luckily, the conflict was ended through an EU- and US-mediated and guaranteed agreement, signed in August 2001. The Ohrid Framework Agreement (OFA), in addition to ending the armed conflict, also provided for a range of legislative and policy measures to ensure equality and minority protection. In November 2001, after a period of inter-party bickering in the aftermath of the conflict, the Macedonian Parliament passed the set of constitutional amendments envisaged by the Ohrid Agreement. A number of laws were then passed, inter alia on local self-government, local finance, municipal boundaries, municipal police, civil service and public administration, electoral districts, the rules of the Assembly, the use of languages, and public attorney.

More precisely, this package of decentralized power, gave official status to a minority language in areas where at least 20 per cent of the population speak it, adopted proportional representation, strengthened education in the Albanian language, and improved participation and employment of minority peoples in public life and state institutions. The Ohrid Framework Agreement also led to the 'double majority' rule, 
meaning that any parliamentary decisions affecting the rights of communities or local self-government must be passed both by a majority of all MPs and a majority of the total number of votes by MPs from the minority community. At the municipal level, Committees for Interethnic Relations have been established in areas with more than 20 per cent minority population. If given a meaningful role, such committees could serve as an important mechanism for preventing majorization of minorities at the local level (Ohrid Framework Agreement, 2001). Nevertheless, it should be noted that the conflict has seriously deteriorated inter-ethnic relations between Macedonians and Albanians living in the country. Today, 16 years after the Ohrid Agreement, interethnic relations in Macedonia still remain burdened by prejudice and stereotypes, rather than cooperation and mutual prosperity.

Moreover, ethnic tensions between Macedonians and Albanians in Macedonia have unfortunately further increased in last several years. Sparked initially by ethnically charged incidents at sports matches, the ethnic tensions between the two communities have soon deteriorated into violence when in February 2012 an off-duty police officer killed two ethnic Albanians in the town of Gostivar, and when five ethnic Macedonians were killed near Lake Smilkovci in April 2012. Both incidents have triggered massive protests of ethnic Albanians and Macedonians respectively, ending in violence and serious damage to civilian properties. Afterwards, there had been a series of attacks on buses and in the streets involving clashes between Macedonians and ethnic Albanian youths, and several youngsters on both sides have been seriously injured (The Sofia Echo, 2012). The situation was further 
worsened when several Albanians were imprisoned and then sentenced for the execution-style murder of five ethnic Macedonians. Thousands of dissatisfied Albanians rioted against the outcome of a politically charged murder trial, thus bringing the country on the brink of another ethnic conflict (Davies, 2014). While this luckily did not happen, interethnic tensions continued to be rather tense, with incidents occurring repeatedly. The situation has once again almost erupted into an armed inter-ethnic conflict, when on May 2015, an armed clash between police and a group of former veterans of the National Liberation Army occurred in Kumanovo. The armed incident saw the death of 8 police officers and 10 members of the armed group, while 30 rebels were imprisoned and charged with terrorism (BBC, 2015). Again, huge demonstrations of Albanians were staged, accusing the government for staging the incident and for abuse of power. The trial is still on-going, and every court session contributes to further increase of inter-ethnic tensions.

\section{FACTORS GENERATING INTER-ETHNIC TENSIONS}

Such strained relations between two major ethnic groups are a result of several factors that often interact with each other. To begin with, much of the tensions resulted due to the different perceptions of the two communities about the underlying concept of the Macedonian state. Albanians argued that Macedonia ought to be the state of equal citizens and ethnicities, but Macedonian elites preferred ethnocentric state where they would have dominant position. Accordingly, as already mentioned, the new constitution favoured ethnic Macedonians by treating them as 
both the only "constitutive nation" as well as a "majority" within the state (Adamson and Jovic, 2004, p. 294). Although, with constitutional changes following the Ohrid Agreement, the preamble of the Constitution has changed in order to reflect the multicultural nature of the state, ethnic Macedonians still perceived Macedonia as their "natural” state (Slaveski and Kozarev, 2012, p. 28). The main argument often goes along the lines that Albanians already have two states (Albania and Kosovo), and therefore it is understandable that Macedonians should have at least one. Therefore, despite on-going claims by Albanians for an official bi-ethnic state system, Macedonians have been very reluctant to move in that direction. Consequently, with such political transformation being formulated as a zero-sum game, the misperception over the basic idea behind the concept of the state continues to be a major cause of inter-ethnic tensions.

The second factor generating inter-ethnic tensions between the two largest communities in Macedonia is the number of Albanians living in the country. According to the last official census held in 2002 the Macedonians comprise 64.18 \% while Albanians $25.17 \%$ of the total population of the country (State Statistical Office, 2010). Although the international community has proclaimed census results as fair and accurate, these results have caused suspicion and dissatisfaction by both Macedonian and Albanian opposition political parties (Alagjozovski and Stavrova, 2003). While Albanian parties claimed that the census figure of 25 per cent was way too low, the Macedonian nationalists believed it was too high, and that the real number of Albanians was smaller than 15 per cent (Gjorgjevski, 2006). It is important noting that the credibility of 
census results was also disputed by Serbs and Turks, who also claim that official census figures represented by the Statistical Agency undermine their factual number (Alagjozovski and Stavrova, 2003). It should be mentioned that the census process often represents a sensitive and highly politicized issue, especially in countries like Macedonia where numbers of ethnic populations are often used as means for gaining certain privileges as well as power distribution. In Macedonia, ethnic census figures undoubtedly play an important role in the distribution of power and resources, but also in policies concerning local governance and finance as well as education and culture (Vrgova, 2015, p. 111). Consequently, the census in Macedonia that was planned for October 2011 has been cancelled four days before its completion date, mainly due to increasing tensions between the two major government coalition partners, the Internal Macedonian Revolutionary Organization Democratic Party for Macedonian National Unity (VMRO-DPMNE) and Democratic Union for Integration (DUI). Officially, the census was suspended since there was a risk that it might not yield reliable data due to differing field interpretations of the surveying methodology. However, it was evident that bot Albanians and Macedonians were trying to make political gains by maximizing their numbers (Karajkov, 2011). The lack of reliable data regarding the ethnic composition of the country for almost 15 years has in turn allowed the continuation of the turf battle about their respective numbers between Macedonian and Albanian parties.

Another factor that spurs ethnic disputes between Macedonians and Albanians comes from differing perceptions about Albanian claims 
deriving from the Ohrid Agreement. While Albanians regard the overall process as an issue of collective and human rights, Macedonians believe that the dispute is actually about territory. Moreover, Albanians view the agreement as a starting point, a dynamic platform from which their overall position will additionally improve in the future. Consequently, for Albanians the Ohrid Agreement represents initial point of departure rather than ceiling of their collective rights (Aziri, 2011, p. 148). On the other hand, although Ohrid Agreement has preserved unitary character of the country, Macedonians remain mistrustful of the Albanians' true intentions, and suspect their claims for more rights as designs for a “greater Albania” or "greater Kosovo” (Fraenkel, 2004). Namely, ethnic Macedonians have argued that independence of Kosovo represents only the first step towards the political unification of all Albanians, setting off a domino effect of secessions by the Albanians of the Republic of Macedonia, followed by the Albanians of Montenegro and southern Serbia (Batt, 2008, p. 5). In this context, Macedonian political elites argue that the ethnic Albanians and other minorities in the country already enjoy minority rights that are in line with the highest standards of international legislation (Daskalovski, 2013, p. 370). However, ethnic Albanians have refused to be considered as an ethnic minority in a Macedonian nation-state, and have claimed collective minority rights well beyond international standards. As a result, continuous tendency of ethnic Macedonians to draw parallels between Albanian demands for increased collective rights in Macedonia and territorial integrity of the country will undoubtedly contribute to further tensions between the two communities. 
Additional factor that has also contributed to inter-ethnic tensions between two major communities in Macedonia is closely linked with Euro-Atlantic integration of the country. Although officially EuroAtlantic integration still represents one of the country's main priorities, Macedonia's membership to NATO and EU has been seriously halted in recent years, mainly due to the unsolved name dispute with Greece. Moreover, support for membership in these two organizations has seriously dropped in recent years by both Macedonian politicians and ethnic Macedonians in general. On the other hand, ethnic Albanians in Macedonia strongly support Euro-Atlantic integration of the country. As mentioned in several occasions by different Albanian politicians throughout the region, Europe and not Greater Albania, represents a viable path towards unification of all Albanians in the Balkans (Sot News, 2014; SETimes. 2008). Although membership to NATO and EU has also been promoted as the main priority of DUI - the Albanian party in the coalition government of Macedonia - at least for the time being such prospects remain rather poor. Such reality, in combination with the above mentioned factors, could seriously contribute to further deterioration of already tense relations between Albanians and Macedonians in the country. The new coalition government led by Social Democratic Union of Macedonia (SDSM) has shown an increased commitment regarding Euro-Atlantic integration of the country as well as towards the unsolved name dispute with Greece. It remains to be seen whether such commitment will translate into concrete results that would eventually de-block Macedonia's path towards NATO and EU, and thus at least partially contribute to relaxation of inter-ethnic relations between Macedonians and Albanians. 


\section{THE CASUALITY BETWEEN INTER-ETHNIC AND INTER-STATE RELATIONS}

In most of the countries in the Western Balkans, inter-ethnic and interstate relations are basically the components of the same equation. In line with this, the inter-ethnic relations between Macedonians and Albanians in Macedonia are often influenced by inter-state relations between Macedonia on the one hand, and Albania and Kosovo, on the other. Consequently, improvements or deteriorations of relations between Macedonia, and Albania and Kosovo, are an important factor that has a direct impact on inter-ethnic relations between the two major ethnicities in the country. At the same time, the opposite is also true; improvements or deteriorations of inter-ethnic relations between Macedonians and Albanians directly influence the bilateral relations between Macedonia and Albania and/or Kosovo. In the case of Macedonia though, such causality between inter-ethnic and interstate relations, is more valid with regard to relations between Macedonia and Kosovo than between Macedonia and Albania. The survey conducted by the Institute for Political Research in Skopje ((IPRS) in March 2016 has shown that 51.4 per cent of citizens in Macedonia have a 'very negative' personal opinion towards Kosovo, while only 22.3 per cent have a 'very positive' one. In the case of Albania, the percentage of those with 'very negative' opinion is 30.1 per cent, while 27.8 per cent of the respondents have expressed a 'very positive' opinion (Institute for Political Research, 2016). Having in mind that the survey has utilised a representative sample that takes into account ethnic composition of the country, it is almost certain that such diametrically different opinions towards Kosovo 
reflect deep inter-ethnic divisions between Macedonians and Albanians. Bellow we will analyse several reasons why Kosovo rather than Albania is much more relevant for the causality between inter-ethnic and interstate relations in Macedonia.

On the one hand, Macedonia and Kosovo have in general shared relatively similar fate throughout the history. Being located in the Balkans - at the crossroads between East and West - both territories have undergone rule of one empire after another. Both Macedonia and Kosovo were former provinces of the Ottoman Empire, and were later both conquered by Serbia in the Balkan wars of 1912-1913. Afterwards, they have for some 80 years been part of the same country, namely the Kingdom of Yugoslavia and the Socialist Yugoslavia. It was the disintegration of the latter that actually enabled independence of both Macedonia and Kosovo. On the other hand, it should be mentioned that the relations between Albanians in Macedonia and Kosovo during the period of former Yugoslavia have been very close. Kosovo has been a common destination for Albanians from Macedonia since it offered educational and employment opportunities that were scarce in Macedonia. In addition, Yugoslavia's unrestricted internal mobility enabled Albanians to migrate and settle in freely throughout the country, resulting in numerous marriages between Albanians from Macedonia and Kosovo as well as kinship ties that still intimately bind many families across these neighbouring territories (International Crisis Group, 1997, p. 5). Through such ties, the events in Kosovo have always resonated in Macedonia, and one might say that Albanians in two countries share similar experiences and aspirations. Consequently, the authorities in 
Skopje and Macedonians in general often see Kosovo as part of the equation of their overall perception about Albanians as the main danger for the Macedonian state.

It is also worth mentioning that in addition to deteriorating inter-ethnic relations between Macedonians and Albanians in Macedonia, the Macedonian conflict of 2001 has seriously damaged relations between Macedonia and Kosovo. Namely, Macedonians and Albanians in the country had totally different views about the causes of the conflict as well as the origin of the insurgents. For most of the Albanians the insurgency was seen as a necessary response to decades of discrimination after all legal efforts had failed (Norwegian Helsinki Committee for Human Rights, 2003, p. 19). As a result, most of the ethnic Albanians expressed their support for the NLA and the insurgency as such, in order for the Albanians to achieve vital political goals. On the other hand, most of the ethnic Macedonians strongly rejected the Albanian argument that the rebellion was a reaction to systematic discrimination of the Albanian population and thus represented a legitimate fight for more rights. For them the insurgency had to be viewed in a regional context, since it was clearly a direct result of the events in Kosovo in 1999. Namely, since NATO intervention in 1999, ethnic Macedonians have claimed that the precarious situation in Kosovo could threaten the stability of Macedonia. In line with that, most of the ethnic Macedonians believed that the conflict in 2001 was a spill-over from Kosovo. The Macedonian politicians similarly to their citizens generally blamed the insurgency on external factors, and refused to ascribe it to Macedonian minority policy. On its address to the nation Prime Minister Ljupco Georgievski insisted 
that the present conflict was the result of aggression planned and led from Kosovo, and even blamed the international community and KFOR troops for allowing "rebel gangs” to "invade Macedonia." (International Crisis Group, 2001, p. 9).

Furthermore, ethnic Macedonians claimed that the NLA was a Kosovo based organisation with Kosovo Albanian leaders and fighters (Buhaug et al., 2008, p. 4). Actually, the origin of the insurgents was from the very beginning one of the biggest problems within the ruling coalition in Macedonia. Namely, VMRO-DPMNE, the strongest party within the government has claimed the crisis to be imported from Kosovo with most of the rebels coming from the province. For instance, Filip Petrovski, at that time a VMRO-DPMNE Member of Parliament, pointed out that "this rebellion is a result of the situation in Kosovo. It is a fact that the NLA are extremist Albanians from Kosovo for whom instability in Macedonia is indispensable to continued criminal activities” (Demjaha, 2012, p. 172). On the other hand, the Albanian coalition partner Democratic Party of Albanians (DPA) has insisted the crisis being of an internal genesis (International Crisis Group, 2001, pp. 5-6). Such differing perceptions have further deepened grievances between two major ethnicities in Macedonia and also left a sense of bitterness and disappointment of Macedonian citizens and politicians towards Kosovo, a fact that shaped relations between the two countries in the years to come.

Another topic around which ethnic divergences in Macedonia were the greatest was independence of Kosovo. Among ethnic Macedonians, the possibility that Kosovo be given independence was a cause of deep 
concern. According to the Brima Gallup March-April 2007 survey, only 3.1 per cent of the ethnic Macedonians were in favour of independence for Kosovo, while 30.5 per cent rather supported an "independent Republic within Serbia” and 33.9 per cent even supported a return to the previous status. The difference with ethnic Albanian views was striking, with 95.3 per cent of the Albanian respondents in Macedonia being in favour of independence (Ragaru, 2008, p. 54). Such strikingly divergent positions have also reflected on differing opinions regarding Kosovo itself. According to the poll conducted by the Institute for Democracy in Skopje 40.4 per cent of the Macedonians had very negative while another 20.6 per cent had negative feelings towards Kosovo. In stark contrast, a high majority of the ethnic Albanians either had very positive (51.5 per cent) or positive (26.9 per cent) feelings for Kosovo (Daskalovski and Taleski, 2008, p. 43). Consequently, one could say that again it is evident that the overall inter-ethnic relations between Macedonians and Albanians in Macedonia heavily depend on inter-state relations between Macedonia and Kosovo and vice versa.

The final occasion when it was seen that in Macedonia inter-ethnic and interstate relations are basically the components of the same equation and that Kosovo rather than Albania is much more relevant for the causality between inter-ethnic and interstate relations in the country was linked with the armed incident in Kumanovo. As already mentioned, during this armed incident in May 2015, 8 police officers and 10 members of the armed group were killed, while 30 rebels were imprisoned and charged with terrorism (BBC, 2015). The incident happened in the midst of the political crisis caused by illegal wire- 
tapping scandal. Fears were high both within the country and internationally that the incident might trigger inter-ethnic tensions and endanger country's already fragile stability. Macedonian authorities were quick to again accuse Kosovo for an act of aggression caused by extremist citizens from Kosovo (Saliu, 2015, p. 95). On the other hand, Albanians staged massive demonstrations and accused the government of staging the incident and of excessive use of power. The opposition party SDSM and many ethnic Macedonians also accused the government of staging the incident in order to deflect the attention from the wiretapping scandal and to provoke inter-ethnic violence (Mejdini, 2016).

Kosovo institutions have immediately distanced themselves from any organized involvement in the armed incident in Kumanovo. The speaker of the Parliament of Kosovo, Kadri Veseli stated that authorities in Kosovo respect the sovereignty of the Republic of Macedonia. However, as an answer to allegations from Macedonia he also said that "there should be more confidence and communication between the political factors in Macedonia to solve the problems” (Hyseni Kelmendi, 2015). Despite such supportive statements coming from Kosovo and the deep suspicion about the event itself, inter-ethnic tensions in Macedonia were quite high for a certain time, while inter-state relations between Macedonia and Kosovo were at very low level. The causality between inter-ethnic relations in Macedonia and interstate relations between Macedonia and Kosovo was again evident. Namely, as already mentioned the survey conducted in March 2016 by the Institute for Political Research has shown diametrically different opinions towards 
Kosovo among Macedonians and Albanians in the country, thus indicating deep inter-ethnic divisions between the two communities.

\section{CONCLUSION}

Traditionally rather problematic inter-ethnic relations between Albanians and Macedonians in Macedonia have continued in a similar manner after independence as well. The newly created state has failed its Albanian minority in terms of advancing their legitimate political and cultural demands - the structural inequalities between the ethnic groups have persisted, thus further fuelling Albanian resentment. As a result, an armed conflict between ethnic Albanian rebels and government forces erupted in 2001. The Ohrid Agreement that ended the conflict, provided for a range of legislative and policy measures to improve the position of the Albanians and other minorities by ensuring equality and minority protection. However, 16 years after the agreement, inter-ethnic relations in Macedonia still remain burdened by prejudice and stereotypes, rather than cooperation and mutual prosperity. Though certain progress has been made, Albanians in Macedonia are still dissatisfied with their position and are claiming more rights at national level. Moreover, ethnic tensions between Macedonians and Albanians in Macedonia have further increased during last several years. The paper has identified and analysed several main factors that contribute to inter-ethnic tensions in the country such as different perceptions about the underlying concept of the Macedonian state, the number of Albanians living in the country, differing perceptions about Albanian claims deriving from the Ohrid Agreement and different positions about the Euro-Atlantic integration. 
As an additional factor, it has been shown that similarly to most of the countries in the Western Balkans, inter-ethnic and interstate relations are basically the components of the same equation. In the case of Macedonia, Kosovo rather than Albania is much more relevant for the causality between inter-ethnic and interstate relations in Macedonia. It may be concluded that the overall inter-ethnic relations between Macedonians and Albanians in Macedonia heavily depend on inter-state relations between Macedonia and Kosovo and vice versa. These factors continue to burden overall inter-ethnic relations between the two biggest communities in the country and could seriously contribute to further deterioration of already tense relations between Albanians and Macedonians.

\section{REFERENCES}

- Adamson, K. \& Jovic, D. (2004). The Macedonian-Albanian political frontier: the re-articulation of post-Yugoslav political identities. Nations and Nationalism, 10(3), 293-311.

- Alagjozovski, R. \& Stavrova, B. (2003, December 8). Macedonia’s Census Opens New Doors. Transitions Online.

- Aziri, E. (2011, October). Inter-ethnic Relations in the Republic of Macedonia before and after the Ohrid Framework Agreement. Balkans: Foreign Affairs, Politics and Socio-Cultures, Epoka University, 131156.

- Balalovska, K. (2006). Macedonia 2006: Towards Stability?. The Ethnobarometer Working Paper Series.

- Batt, J. (2008, January). Introduction. In Judy Batt eds., Is there an Albanian question?. Chaillot Paper No. 107, Institute for Security Studies, Paris.

- $\quad$ Buhaug, H., Ringdal, K., Simkus, A. \& Listhaug, O. (2008, August 2831). Ethnic Polarization and Post-Conflict Animosity: The Case of 
Macedonia. Centre for the Study of Civil War, International Peace Research Institute, Annual Meeting of the American Political Science Association, Boston.

- Daskalovski, Zh. (2014). Census taking and inter-ethnic relations in Macedonia. Southeast European and Black Sea Studies, 13(3), 365379.

- Daskalovski, Zh. (2003). The Right to Rebel: The National Liberation Army and the Macedonian Crisis of 2001. Romanian Journal of Political Science, 3(2), 51-69.

- Daskalovski, Zh. \& Taleski, D. (2008). The independence of Kosovo and the consolidation of Macedonia-A reason to worry? In Cutting or tightening the Gordian Knot?, ed. E.M. Felberbauer, P. Jureković, and F. Labarre. Vienna: National Defence Academy and Bureau for Security Policy at the Austrian Ministry of Defence, 29-57.

- Davies, J. (2014, July 15). Is Macedonia on the brink of another ethnic conflict?. Vice. Retrieved from http://www.vice.com/read/albanians-inmacedonia-are-pissed-off-jack-davies-777 (27.10.2016).

- Demjaha, A. \& Peci, L. (2015). Insurgencies in the Balkans: Albanian Liberation Armies. In Albrecht Schnabel and Rohan Gunaratna eds. Wars From Within: Understanding and Managing Insurgent Movements. London: Imperial College Press.

- Demjaha, A. (2012). The role of Euro-Atlantic integration processes on the relations between Macedonia and Kosovo during the 2001 conflict. Evrodijalog 17, 169-186.

- Fraenkel, E. (2004) Macedonia. In Nations in transit 2003. New York: Freedom House.

- Gjorgjevski, B. (2006, March 18). Albancite se pomalku od 15 otsto od naselenieto vo Makedonija [The Albanians are less than $15 \%$ of the Macedonian population]. Dnevnik.

- Glenny, M. (1996). The Fall of Yugoslavia. London: Penguin Books.

- Hyseni Kelmendi, V. (2015, May 15). The Pristina reactions after Kumanovo. Osservatorio Balcani e Caucaso. Retrieved from https://www.balcanicaucaso.org/eng/Areas/Kosovo/The-Pristinareactions-after-Kumanovo-161555 
- International Crisis Group (1997, October 21). Macedonia Report: The Politics of Ethnicity and Conflict. ICG Europe Report No. 26, Skopje/Brussels.

- International Crisis Group (2001, April 05). The Macedonian Question: Reform or Rebellion. ICG Balkans Report No. 109, Skopje/Brussels.

- International Crisis Group (2001, June 20). Macedonia: The Last Chance for Peace. ICG Balkans Report No. 113, Skopje/Brussels.

- Karajkov, R. (2011, October 20). Census fails in Macedonia. Osservatorio Balcani e Caucaso - Transeuropa. Retrieved from http://www.balcanicaucaso.org/eng/ Areas/Macedonia/Census-fails-inMacedonia105372

- Macedonia charges 30 with terrorism after Kumanovo clashes (2015, May 11). BBC News. Retrieved from http://www.bbc.com/news/worldeurope-32695909

- Macedonia blames Kosovans for deadly clash (2015, May 10). Al Jazeera News. Retrieved from http://www.aljazeera.com/news/2015/05/macedonia-policemen-killedbattle-armed-group-150509213341943.html

- Mejdini, F. (2016, May 10). Macedonia’s Kumanovo Shootout Still Raising Suspicions. Balkan Insight. Retrived from http://www.balkaninsight.com/en/article/macedonia-s-kumanovoshootout-still-raising-suspicions-05-10-2016

- Norwegian Helsinki Committee for Human Rights (2003). Conflicting Perceptions: A study of prevailing interpretations of the conflict in Macedonia among Albanian and Macedonian communities. Report 1, Oslo.

- Ohrid Framework Agreement (2001, August 13).

- Ortakovski,V. (2001). Interethnic Relations and Minorities in the Republic of Macedonia. Southeast European Politics, 2(1), 24-45.

- Petroska-Beska, V. \& Najcevska, M. (2004, February). Macedonia: Understanding History, Preventing Future Conflict. Special Report 115, Washington DC: United States Institute of Peace.

- Public Opinion Regarding the 'Name Dispute,' Perceptions about Macedonian-Greek Relations and EU and NATO Integrations (2016). 
Institute for Political Research, Skopje. Retrieved from ipis.org.mk/wp.../IPIS_Istrazuvanje_Prezentacija-21-juni-2016.pptx

- Rama: Projekti ynë aktual është Evropa e Madhe, jo Shqipëria e Madhe (2014, October 21). Sot News. Retrieved from http://www.sot.com.al/politike-intervista/rama-projekti-yn\%C3\%ABaktual-\%C3\%ABsht\%C3\%AB-evropa-e-madhe-jo-shqip\%C3\%ABriae-madhe\#sthash. wfFAbb7n.dpuf

- Ragaru, N.. (2008, January). Macedonia: Between Ohrid and Brussels. In Judy Batt eds., Is there an Albanian question?, Chaillot Paper No. 107, Institute for Security Studies, Paris.

- Saliu, H. (2015). The propaganda and the image of Kumanova incident. Thesis, 2, AAB University, 95-104.

- Simoska, E. (1997). Macedonia: a View on the Inter-Ethnic Relations. Perceptions: Journal of international affairs, 2(2), 93-103.

- Situation in Macedonia calmer but inter-ethnic tensions with Albanians linger (2012, March 14). The Sofia Echo. Retrieved from http://sofiaecho.com/2012/03/14/1787294_situation-in-macedoniacalmer-but-inter-ethnic-tensions-with-albanians-linger

- Slaveski, S. \& Kozarev, A. (2012). Europeanization’ of the Macedonian National Identity. The Western Balkans Policy Review, 2(1), 21-38.

- The Census of Population, Households and Dwellings in the Republic of Macedonia (2005). Skopje: State Statistical Office.

- Topi thotë se e ardhmja e Shqipërisë është Evropa, jo Shqipëria e madhe (2008, July 14). SETimes. Retrieved from http://www.setimes.com/cocoon/setimes/xhtml/sq/features/ setimes/newsbriefs/2008/07/14/nb-05

- Vrgova, R. (2015). Census, Identity, and the Politics of Numbers: The Case of Macedonia. Contemporary Southeastern Europe, 2(2), 107-125. 